\title{
Assessment of nutritional status and quality of life in patients with pancreatic head cancer.
}

\author{
Imane boussenna ${ }^{1,2}$, Mohamed Acharki ${ }^{3}$, Zineb Hannoun ${ }^{2}$, Ikram Kenfaoui ${ }^{4}$, and Abdellatif Bour ${ }^{2}$ \\ 'Research Laboratory Innovation \& Information System, EuRSED Vienne France. \\ ${ }^{2}$ Laboratory of Biology and Health (LBS), Food and Health Nutrition Sciences Team (ESNAS),University Ibn Tofail, Morocco \\ ${ }^{3}$ Department of functional and digestive operating, Ibn Sina 'University Hospital, Rabat, Morocco \\ ${ }^{4}$ Natural Resource and Sustainable Development Laboratory, Faculty of Science, Kenitra, Morocco
}

Corresponding author email: Imaneboussenna@gmail.com

\begin{abstract}
The aim of this study is to evaluate the nutritional status and quality of life (QOL) in patients with unresectable pancreatic head cancer. This is a retrospective assessment that included different parameters namely: current weight, weight loss, body mass index (BMI), bilirubin level (BT), serum albumin (ALB) and C-reactive protein (CRP). Protein-calorie malnutrition was defined by the nutritional risk index (NRI) and quality of life by the general quality of life in digestive disease score (GIQL). The study included 50 patients $(60 \%$ men, $40 \%$ women) with a mean age of $61.8 \pm 13.5$ years. 32 patients had locally advanced tumors and 16 had metastatic tumors. All patients had significant weight loss [median $24.9 \%$ (2\%-37\%) of stable pre-disease weight], BMI was less than $18.5 \mathrm{~kg} / \mathrm{m}^{2}$ in $66 \%\left(18.28 \pm 3.6 \mathrm{~kg} / \mathrm{m}^{2}\right)$. Bilirubin was greater than $200 \mathrm{mg} / \mathrm{l}$ in $44 \%$, ALB less than $35 \mathrm{~g} / \mathrm{l}$ in $92 \%$ and CRP greater than $6 \mathrm{mg} / \mathrm{l}$ in $84 \%$ of patients. Severe undernutrition was present in $73 \%$ of patients and moderate undernutrition in $27 \%$. The GIQL score was satisfactory in $73 \%$ of the patients. These results show that this cancer has a serious impact on nutritional status, hence the need to manage these patients in order to mitigate nutritional exhaustion and improve their quality of life.
\end{abstract}

Keywords: Pancreatic head Cancer, Assessment, Nutritional Status, Quality of life. 


\section{Introduction}

Cancer of the head of the pancreas is the 6th digestive cancer in terms of frequency and represents $2.5 \%$ of cancers [1]. This percentage is very close to that recorded in Rabat; in fact it represents $2.9 \%$ of all cancers, thus ranking ninth among male cancers and $1.8 \%$ of all cancers in women, ranking twelfth among female cancers [2].

It is a serious public health problem [3] since mortality rates are almost identical to incidence rates, due to the late clinical presentation of symptoms [4]. In $80 \%$ of cases, cancer is diagnosed only at the metastatic stage [5].

At the time of diagnosis, curative tumor resection is only possible in $10-15 \%$ of subjects, leaving a large population with a poor prognosis and limited therapeutic options [6]. This cancer is capable of inducing biliary obstruction which may induce jaundice following bile excretion. This obstruction may be complicated by superinfection and undernutrition, with patients often reporting decreased food intake accompanied by pain, nausea or vomiting. Although pancreatic head cancer is associated with poor nutritional status and quality of life, few data on these aspects are available [5]. Therefore, we sought through this study to assess the nutritional status and quality of life of patients with pancreatic head cancer.

\section{Materials and methods}

50 patients with head pancreatic cancer were included in the period between January 2015 and March 2020 at the department of functional and digestive operations of Ibn Sina University Hospital, Rabat, Morocco. The group included 60\% men and 40\% women with a mean age of 62 years.

The study is based on data collected from the patients' medical records. The data of each patient are listed according to the following parameters:

- Demographic data (age, gender)

- Surgical and medical history

- Anthropometric parameters

- Biological parameters

- Nutritional risk factor

- Quality of life assessment

\subsection{Anthropometric parameters}

For all patients we recorded height $(\mathrm{cm})$, normal weight before the disease, current weight in $\mathrm{kg}$ and weight loss during the last 6 months in \%. The body mass index (BMI, $\mathrm{kg} / \mathrm{m}^{2}$ ) was calculated by dividing the weight in $\mathrm{kg}$ by the height in $\mathrm{m}^{2}$. A patient with a $\mathrm{BMI}<18.5 \mathrm{~kg} / \mathrm{m}^{2}$ is under weight, weight and normal if $18.5<\mathrm{BMI}<24.9 \mathrm{~kg} / \mathrm{m}^{2}$ and the patient is overweight if $\mathrm{BMI}>29.9 \mathrm{~kg} / \mathrm{m}^{2}$.

\subsection{Biological parameters}

Biological parameters in was taken from the blood test results of patients obtained from medical records.

\subsection{Nutritional risk factor}

The nutritional risk factor is determined by assessing protein-calorie malnutrition using the nutritional risk index (NRI) [7] calculated by the following equation:

\section{$N R I=1.519 \times$ Albumin $(g / l)+0.417$ (Current Weight) Normal Weight) $x 100$}

A patient was considered severely malnourished if $\mathrm{NRI}<83.5$, malnutrition and moderate NRI $\geq 83.5$ 97.5. Nutritional status was considered normal if NRI $\geq 97.5$.

\subsection{Quality of life assessment}

We assessed the quality of life of patients using the General Quality of Life in Digestive Diseases (GIQL) score. Each question was scored from 0 to 4 (from the least desirable to the most desirable answer). Scores below 55 were considered "unsatisfactory", score $\geq$ 55-70 "satisfactory", scores $\geq 70-80$ "largely satisfactory" and those $\geq 80$ "very satisfactory" [5].

\section{Results}

\section{1 characteristics of patients:}

The characteristics of the patients included in the study are presented in Table 1 .

Table 1. Patient characteristics.

\begin{tabular}{|l|r|}
\hline \multicolumn{1}{|c|}{ Patients } & N=50 \\
\hline Female & $20(40 \%)$ \\
\hline Male & $30(60 \%)$ \\
\hline Mean age (years) & $61.8(13.5)$ \\
\hline Tumor status $\quad 2$ \\
$\cdot \quad$ Localized $\quad$ Locally advanced & 32 \\
$\cdot \quad \quad$ Metastatic & 16 \\
\hline Previous treatment ${ }^{1}$ & 1 \\
\hline Previous surgery ${ }^{2}$ & 5 \\
\hline N : Number of patients \\
'Previous treatment : Type 2 diabetes \\
2Previous surgery: bile duct surgery (N=2), Cholecystectomy (N=1), \\
Hemorrhoid (N=1), fibroid (N=1).
\end{tabular}




\subsection{Nutritional assessment:}

The results of the assessment of the nutritional status are presented in table 3

\subsubsection{Anthropometric parameters:}

The evaluation of the patients' weight showed that the average weight was $52.9 \pm 8.8 \mathrm{~kg}$ and the average BMI was $18.28 \pm 3.6 \mathrm{~kg} / \mathrm{m}^{2} .33$ patients were underweight with a $\mathrm{BMI}<18.5 \mathrm{~kg} / \mathrm{m}^{2}$ and 15 were normal weight $\left(\mathrm{BMI}<25 \mathrm{~kg} / \mathrm{m}^{2}\right)$. Among all the patients studied 40 had lost more than $20 \%$ of their normal pre-disease weight during the last 6 months with an average of $24.9 \%(2 \%-37 \%)$.

\subsubsection{Biological parameters}

The blood test results of the patients showed that albumin level was less than $35 \mathrm{~g} / 1$ in $92 \%$ of the patients [median $29.35 \mathrm{~g} / \mathrm{l}(18-41)$ ], while c-reactive protein was more than $6 \mathrm{mg} / \mathrm{l}$ in $84 \%$ [median $89.51 \mathrm{mg} / \mathrm{l}$ (5-360)]. A significant correlation was found between weight loss and CRP $(r=0.26$, $p=0.000$ ) (Figure 1). Bilirubin was greater than $200 \mathrm{mg} / 1$ in $44 \%$ and between $100 \mathrm{mg} / 1$ and $200 \mathrm{mg} / 1$ in 3

\subsubsection{Nutritional risk factor}

The nutritional risk index (NRI) showed that $73 \%$ of patients had severe undernutrition $(\mathrm{NRI}<83.5), 27 \%$ had moderate undernutrition with $83.5<\mathrm{NRI}<97.5$, no patient had normal nutritional status. A significant correlation was found between serum albumin level and nutritional risk index $(\mathrm{r}=0.61, \mathrm{p}=0.000)$ (Figure 2$)$. It was found in the present study that the nutritional status of the patients has a close relationship with the bilirubin level, as shown in table 2. A high bilirubin level resulted in severe undernutrition in $80 \%$ of the patients, among them $38 \%$ had a BT $>200 \mathrm{mg} / 1$.

\subsubsection{Quality of life assessment}

Quality of life was assessed in 15 patients. This assessment showed that overall quality of life was satisfactory in $73 \%$ of patients and no patient had an unsatisfactory quality of life.

Table 2. The relationship between Bilirubin level (BT) and the nutritional risk index (NRI)

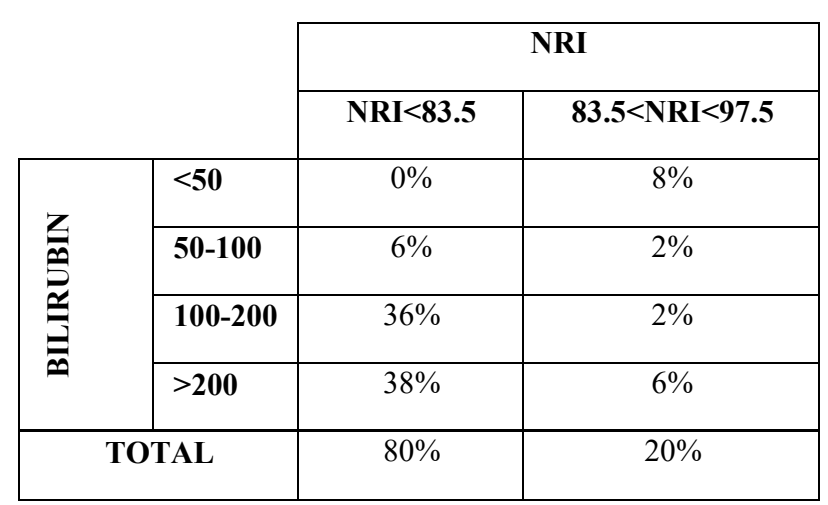

Table 3: Result of the nutritional assessment

\begin{tabular}{|c|c|c|c|}
\hline Parameters & Mean or median & Reference value & Number of patients \\
\hline Height $(\mathrm{cm})$ & $168 \mathrm{~cm}(6)$ & & \\
\hline Weight (kg) & $52.9 \mathrm{~kg}(8.8)$ & & \\
\hline BMI $\left(\mathrm{kg} / \mathrm{m}^{2}\right)$ & $18.2 \mathrm{~kg} / \mathrm{m}^{2}(2.63)$ & $\begin{array}{c}\mathrm{BMI}<18.5 \mathrm{~kg} / \mathrm{m}^{2} \\
\mathrm{BMI}<25 \mathrm{~kg} / \mathrm{m}^{2}\end{array}$ & $\begin{array}{l}\mathrm{N}=33 \\
\mathrm{~N}=15\end{array}$ \\
\hline Weight loss (\%) & $24.9 \%(2-37)$ & Weight loss $>20 \%$ & $\mathrm{~N}=40$ \\
\hline NRI & $74.59(8.1)$ & $\begin{array}{c}\text { NRI }<83.5 \\
83.5<\text { NRI }<97.5\end{array}$ & $\begin{array}{c}\mathrm{N}=43 \\
\mathrm{~N}=7\end{array}$ \\
\hline $\begin{array}{l}\text { Serum Albumin } \\
\text { (ALB) }\end{array}$ & $29.35 \mathrm{~g} / \mathrm{l}(4.3)$ & ALB $<35 \mathrm{~g} / \mathrm{l}$ & $\mathrm{N}=45$ \\
\hline $\begin{array}{l}\text { C-reactive protein } \\
\text { (CRP) }\end{array}$ & $89.51 \mathrm{mg} / \mathrm{l}(5-30)$ & CRP>6mg/l & $\mathrm{N}=42$ \\
\hline Bilirubin (BT) & $\begin{array}{c}186.24 \mathrm{mg} / \mathrm{l} \\
(94.58)\end{array}$ & $\begin{array}{c}\text { BT }<50 \mathrm{mg} / \mathrm{l} \\
50 \mathrm{mg} / \mathrm{l}<\mathrm{BT}<100 \mathrm{mg} / \mathrm{l} \\
100 \mathrm{mg} / \mathrm{l}<\mathrm{BT}<200 \mathrm{mg} / \mathrm{l} \\
\mathrm{BT}>200 \mathrm{mg} / \mathrm{l}\end{array}$ & $\begin{array}{l}\mathrm{N}=5 \\
\mathrm{~N}=4 \\
\mathrm{~N}=19 \\
\mathrm{~N}=\mathbf{2 2}\end{array}$ \\
\hline
\end{tabular}




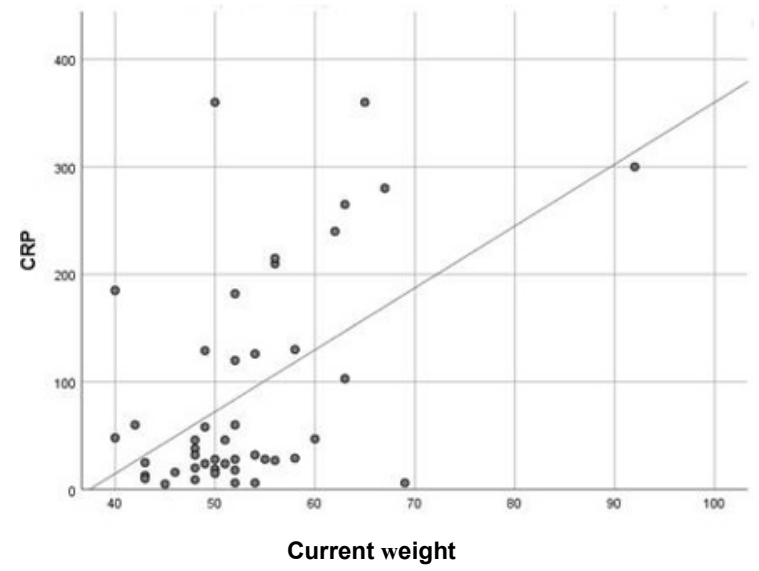

Figure 1: Significant correlation between current patient weight and C-reactive protein (CRP) $(r=0.26, p=0.000)$

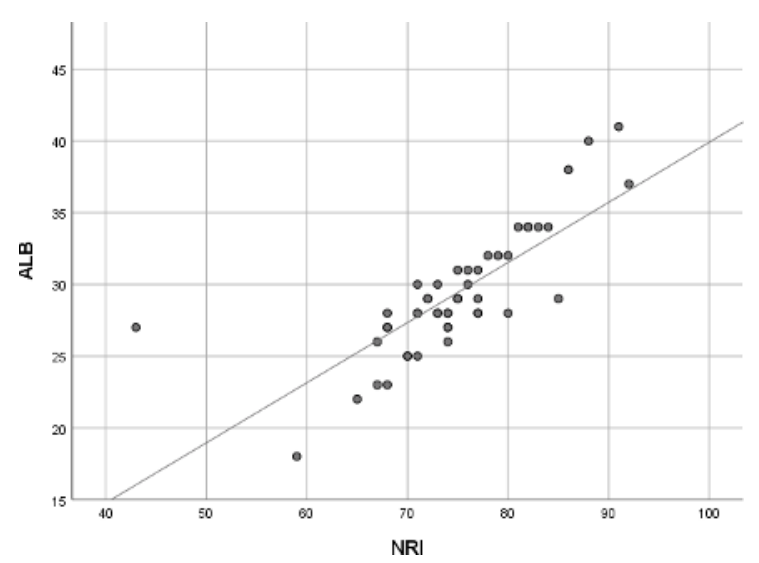

Figure 2: Significant correlation between the nutritional risk index (NRI) and serum albumin (ALB) $(r=0.61, p=0.000)$.

\section{Discussion}

The aim of our study was to evaluate the nutritional status of patients with unresectable pancreatic head cancer through the analysis of several parameters. The results obtained clearly showed that this disease has a profound and visible impact on nutritional status.

This study showed that $100 \%$ of the patients studied had a significant weight loss and that in $80 \%$ of these patients this loss exceeded $20 \%$ of the stable weight before the disease, with an average of $24.9 \%$. BMI was less than $18.5 \mathrm{~kg} / \mathrm{m} 2$ in $60 \%$. This is consistent with another study that showed a significant weight loss in their patients [5]. D.H. Bicakli et al found a BMI between $18.5 \mathrm{~kg} / \mathrm{m} 2$ and $25 \mathrm{~kg} / \mathrm{m} 2$ in $56.3 \%$ [8].

Serum albumin which is considered as a marker of nutritional status in cancer patients [9] was significantly reduced, 92\% had an albumin below $35 \mathrm{~g} / \mathrm{l}$. As observed in another study weight loss and low serum albumin concentrations were significantly marked in pancreatic head cancer patients [10]. These low serum albumin levels in these cancer patients can be explained by chronically reduced food intake and protein-calorie malnutrition which explains the significant correlation $(r=0.61, p=0.000)$ found between serum albumin and the nutritional risk index (NRI).

The c-reactive protein was elevated in $84 \%$ of the patients studied. The increase in CRP level may have a relationship with tumor status, a patient with a metastatic tumor has a higher CRP than a patient with a localized or locally advanced tumor. One study showed that the rate at which CRP increased accelerated with the development of the disease [11]. The relationship between high levels of c-reactive protein (CRP) and weight loss may be explained by the low food intake and demand for amino acids to produce protein, which results in continuous catabolism and contributes to progressive weight loss [11].

Undernutrition is also related to the increase in bilirubin level due to biliary obstruction, as shown in Table $3,74 \%$ of patients with bilirubin level above $100 \mathrm{mg} / \mathrm{l}$ were severely undernourished.

The study of the patients' quality of life by the GIQL score showed that the overall quality of life was satisfactory in $73 \%$ of the patients, which is in line with the results obtained in another study [5]. This can be explained by the fact that patients adapt to their new clinical situation and adjust their expectations regarding quality of life [5].

These results obtained coincide with the results obtained in other study previously carried out and which confirms that pancreatic cancer alters the nutritional status of patients in a rapid and profound way.

\section{Conclusion}

Pancreatic cancer has a serious impact on the nutritional status of patients and induces undernutrition in the majority of cases. This has a negative influence on the prognosis of the disease [12]. The assessment of the nutritional status of these patients is strongly recommended, for an effective management to alleviate nutritional depletion and improve their quality of life. 


\section{References}

1. A. Aomari, M. Firwana, A. Rahaoui, M. Bakkali, R. Afifi, EA. Essaid: Pancreas cancer : epidemiologicals,clinicals,morphologicals aspects, and therapeutic modalities. Result of a moroccan university center, Annales des Sciences de la Santé $N^{\circ}$ 13, Vol. 1: 13-22 (2017)

2. N. Essafi : Epidémiologie des tumeurs du pancréas à propos de 62 cas , Université Mohamed V , Faculté de médecine (2019).

3. A.-C. Lefebvrea,*, J. Maurelb, S. Boutreuxb, V. Bouvier b, J.-M. Reimunda, G. Launoyb, D. Arsenea : Pancreatic cancer: Incidence, treatment and survival trends - 1175 cases in Calvados (France) from 1978 to 2002, Gastroentérologie Clinique et Biologique 33, 1045—1051(2009)

4. S. Y. Kim, G. A. Wie, W. J. Lee, S. Park, S. M. Woo : Changes in Dietary Intake, Body Weight, Nutritional Status, and Metabolic Rate in a Pancreatic Cancer Patient. Clin Nutr Res;2:154158(2013)

5. J. E. Witvliet-van Nierop, C. M. LochtenbergPotjes, N. J. Wierdsma, H. J. Scheffer, G.Kazemier, K. Ottens-Oussoren, M. R. Meijerink, and M. A. E. de van der Schueren : Assessment of Nutritional Status, Digestion and Absorption, and Quality of Life in Patients with Locally Advanced Pancreatic Cancer. Hindawi Gastroenterology Research and Practice Volume 2017, Article ID 6193765, 7 pages (2017).

6. SJ .Wigmore, CE. Plester, RA .Richardson and $\mathrm{KCH}$. Fearon :Changes in nutritional status associated with unresectable pancreatic cancer. British Joumal of Cancer 75(1), 106-109 (1997).

7. F. J. Padillo, B. Andicoberry, J. Muntane, J .M. Lozano, G. Mino, A. Sitges-Serra, C. PeraMadrazo : Factors Predicting Nutritional Derangements in Patients with Obstructive Jaundice: Multivariate Analysis. World J. Surg. $25,413-418,(2001)$.

8. D.H Bicakli, R. Uslu, S. C Guney and A. Cokerc :The Relationship Between Nutritional Status, Performance Status, and Survival Among Pancreatic Cancer Patients, nutrition and cancer (2019).
9. J. Bachmann, K. Ketterer, C. Marsch, K. Fechtner, H. Krakowski-Roosen, M.W Büchler, H. Friess and M. E. Martignoni : Pancreatic cancerrelated cachexia: influence on metabolism and correlation to weight loss and pulmonary function, BMC Cancer, 9:255 (2009).

10. J. Kang, J. S. Park, D.S. Yoon, W. J. Kim, H-y. Chung, S. M. Lee, N. Chang: A Study on the Dietary Intake and the Nutritional Status among the Pancreatic Cancer Surgical Patients. Clin Nutr Res. Oct;5(4):279-289 (2016).

11. M. D. Barber, J. A. Ross \& K. C. H. Fearon (1999) Changes in Nutritional, Functional, and Inflammatory Markers in Advanced Pancreatic Cancer, Nutrition and Cancer, 35:2, 106-110 (2009).

12. I. Azghari - A. Boukir : Dénutrition et cancers digestifs : du diagnostic à la prise en charge. J. Afr. Hépatol. Gastroentérol (2015). 